\title{
Interactive Effects of Mycorrhizal Inoculation and Organic Soil Amendments on Nitrogen Acquisition and Growth of Highbush Blueberry
}

\author{
Wei Qiang Yang, ${ }^{1}$ Barbara L. Goulart, ${ }^{2}$ K. Demchak, ${ }^{3}$ and Yadong Li $^{4}$ \\ Department of Horticulture, The Pennsylvania State University, University Park, PA 16802
}

\begin{abstract}
AdDitional INDEX WORDs. ericoid mycorrhizae, nitrogen isotope $15, \mathrm{C}$ to $\mathrm{N}$ ratio, soil amendment, Vaccinium corymbosum
Abstract. The ability of mycorrhizal and nonmycorrhizal 'Elliott' highbush blueberry (Vaccinium corymbosum L.) plants to acquire soil $\mathrm{N}$ under different preplant organic soil amendment regimes (forest litter, rotted sawdust, or no amendment) was investigated in a field experiment using ${ }^{15} \mathrm{~N}$ labeled $\left(\mathrm{NH}_{4}\right)_{2} \mathrm{SO}_{4}$. Plants inoculated with an ericoid mycorrhizal isolate, Oidiodendron maius Dalpé (UAMH 9263), had lower leaf ${ }^{15} \mathrm{~N}$ enrichment and higher leaf $\mathrm{N}$ contents than noninoculated plants but similar leaf $\mathbf{N}$ concentrations, indicating mycorrhizal plants absorbed more nonlabeled soil N than nonmycorrhizal plants. Mycorrhizal plants produced more plant dry weight (DW) and larger canopy volumes. The effect of preplant organic amendments on the growth of highbush blueberry plants was clearly demonstrated. Plants grown in soil amended with forest litter produced higher DW than those in either the rotted sawdust amendment or no amendment. Plants grown in soils amended preplant with sawdust, the current commercial recommendation, were the smallest. Differences in the carbon to nitrogen ratio were likely responsible for growth differences among plants treated with different soil amendments.
\end{abstract}

Ericoid mycorrhizal fungi can degrade organic $\mathrm{N}$ and transfer it to mycorrhizal plants in experiments in controlled environments (Abuzinadah and Read, 1986; Read, 1991; Read et al., 1989). Degradation of organic N sources such as proteins relies on acid extracellular protease produced by ericoid mycorrhizal fungi (Bajwa and Read, 1985; Bajwa et al., 1985; Read, 1991). It is hypothesized that external hyphae of infected root cells provide channels for transfer of organic $\mathrm{N}$ compounds such as amino acids and short peptides to the host plants (Bajwa and Read, 1985, 1986; Stribley and Read, 1980). These two important aspects of ericoid mycorrhizal function have been regarded as essential mechanisms for $\mathrm{N}$ nutrition of ericoid mycorrhizal hosts in acidic organic soils (Read, 1991). A recent study suggested that ericoid mycorrhizae enabled the host plants to access soil organic $\mathrm{N}$ sources under natural conditions (Michelsen et al., 1996). Although the role of ericoid mycorrhizae in host $\mathrm{N}$ use seems to be well defined in natural ecosystems, it is not known whether this mechanism exists or if it is important in agroecosystems.

Production of highbush blueberry (Vaccinium corymbosum L.) in mineral soils has relied on soil acidification, organic mulch, and preplant soil amendments (Gough et al., 1977; Goulart et al., 1996b). Surveys in such production systems have found large variation of mycorrhizal infection levels (Boyer et al., 1982; Goulart et al., 1993; Jacobs et al., 1982), which may be the result of the combined effects of soil $\mathrm{pH}, \mathrm{N}$ fertilizer inputs, and organic matter source among different sites (Stevens et al., 1996). A diverse fungal symbiont community has also been isolated and identified in these production systems (Stevens et al., 1996). Field studies have demonstrated that mycorrhizal infection levels are affected by $\mathrm{N}$ application rates and organic mulch (Goulart et al., 1995a, 1996a). A preliminary field inoculation study by the

Received for publication 10 July 2000. Accepted for publication 22 Apr. 2002. ${ }^{1}$ Former graduate research assistant and corresponding author. Current address: North Willamette Research and Extension Center, 15210 NE Miley Road, Aurora, OR 97002; e-mail wei.yang@orst.edu.

${ }^{2}$ Former associate professor.

${ }^{3}$ Senior extension associate.

${ }^{4}$ Visiting professor. Current address: Department of Horticulture, Jilin Agricultural University, Chang Chun 130118, People's Republic of China. authors found that growth of highbush blueberry plants was reduced when soils were amended with rotted sawdust (Yang et al., 1998). A probable mechanism is competition for $\mathrm{N}$ by microbes involved in the breakdown of the sawdust. Therefore, it is likely that the ability of the host plant to acquire $\mathrm{N}$ is affected by the type of preplant organic matter, as well as by mycorrhizal infection level, and the characteristics of its fungal symbiont. Therefore, the following research was conducted to investigate the interactive effects of mycorrhizal infection and organic soil amendments on $\mathrm{N}$ acquisition in highbush blueberry under field conditions.

\section{Materials and methods}

A $2 \times 3 \times 2$ factorial experiment was conducted at the Horticultural Experiment Farm at the Russell E. Larsen Agricultural Research Center, Rock Springs, Pa. The soil was a Hagerstown silt loam (mesic Typic Hapludalfs) with no history of ericaceous plantings. Treatment factors consisted of two mycorrhizal treatments (inoculated vs. noninoculated), three preplant soil amendment treatments (forest litter, sawdust, and no amendment) and two labeled-N treatments $\left(0\right.$ or $0.1 \mathrm{~g}{ }^{15} \mathrm{~N}$ labeled $\left(\mathrm{NH}_{4}\right)_{2} \mathrm{SO}_{4} /$ plant). Inoculated and uninoculated plots were separated by a $3 \mathrm{~m}$ buffer zone to reduce potential cross contamination during the experiment. Treatments were arranged in a split-plot design with five replications, all of which were trickle irrigated. Plots were overlaid with silver surfaced-black base $0.03 \mathrm{~mm}$ polyethylene film. Soil amendment and labeled $\mathrm{N}$ treatments were randomly assigned within the main plot (mycorrhizal treatments). The organic amendments (forest litter and rotted sawdust) were mixed with soil from each planting hole at a 1:1 (by volume) ratio before fumigation. Forest litter was collected from a private oak (Quercus L. sp.) forest with an understory of mixed ericaceous species in the Bald Eagle Valley in central Pennsylvania. Rotted sawdust was 4 years old, and made up primarily of oak. The $\mathrm{C}$ to $\mathrm{N}$ ratio of each organic amendment was determined by using a EA 1108 Elemental Analyzer (FISONS Instruments S.P.A., Rome).

Because the fungi that form the ericoid mycorrhizal symbiosis are ubiquitous, and capable of living saprophytically in soils 
Table 1. ANOVA for growth parameters of 'Elliott' highbush blueberry in a three factor factorial experiment $(\mathrm{MI} \times \mathrm{SA} \times \mathrm{N}){ }^{\mathrm{z}}$

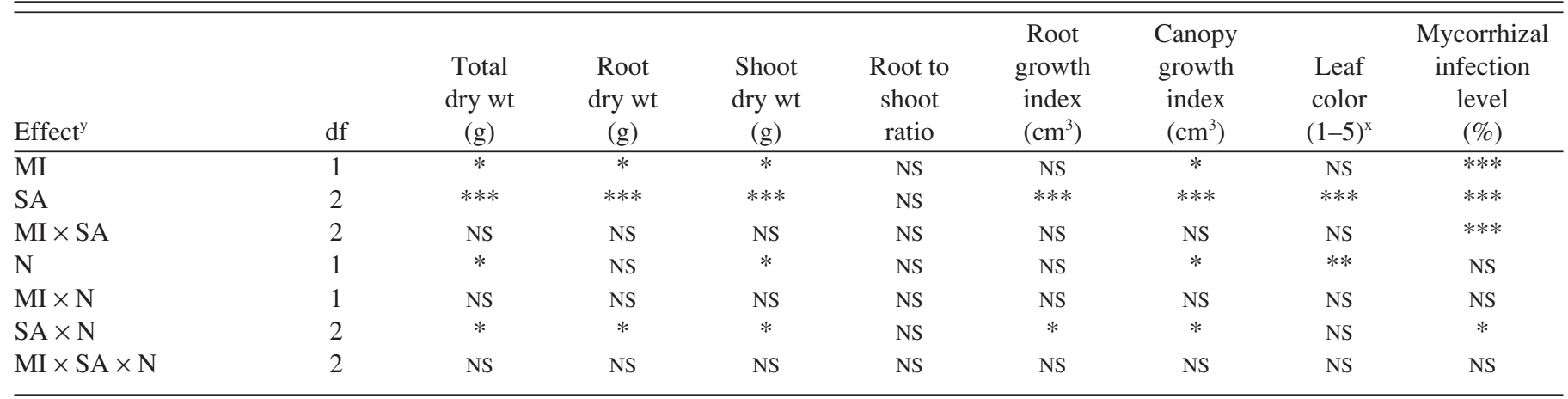

${ }^{\mathrm{z}} \mathrm{MI}=$ mycorrhizal inoculation, $\mathrm{SA}=$ soil amendment, and $\mathrm{N}=$ labeled $\mathrm{N}$ treatment.

${ }^{y}$ Effect was adjusted using initial growth index as a covariate except for dependent variables of leaf color and infection.

${ }^{\mathrm{x}} 1=$ reddish yellow, $5=$ dark green .

Ns,******** Nonsignificant or significant at $P=0.05,0.01$, or 0.001 , respectively.

(Barron, 1962), the entire experimental plot was fumigated with a 67 methyl bromide : 33 chloropicrin $(\mathrm{v} / \mathrm{v})$ mixture at the rate of $560 \mathrm{~kg} \cdot \mathrm{ha}^{-1}$, which is sufficient to eliminate indigenous ericoid mycorrhizal fungi in the soil and/or in the organic amendments (Yang et al., 1998). Two weeks after fumigation, the soil $\mathrm{pH}$ at each planting hole was determined and the amount of elemental sulfur $(\mathrm{S})$ powder needed to decrease soil $\mathrm{pH}$ to 5.0 was calculated and mixed into each planting hole. It was found that mixing elemental $\mathrm{S}$ powder into the soil following fumigation was effective to decrease soil $\mathrm{pH}$ to the desired value (Yang et al., 1998). Following the $S$ amendment, 'Elliott' highbush blueberry plants, which had been propagated by rooting meristem tip cultured blueberry shoots in acid-washed sand, were produced as described previously (Yang and Goulart, 1997), acclimatized in the greenhouse, and transplanted in the field on 28 June 1998. The within row spacing was $2 \mathrm{~m}$ and between row spacing $3 \mathrm{~m}$. There were a total of 60 plants with no guard row being planted.

Mycorrhizal inocula were prepared by growing a pure strain of Oidiodendron maius (UAMH9263), isolated previously from the roots of a local native lowbush blueberry (V. angustifolium L.) population (Stevens et al., 1996) in liquid Mitchell-Read medium (Mitchell and Read, 1981). The 20-d-old liquid fungal culture was filtered through Whatman No. 1 paper. Fungal mycelia were washed with sterile distilled water five times and macerated in $100 \mathrm{~mL}$ of sterile distilled water using a blender. Plants were inoculated during planting by evenly pouring $20 \mathrm{~mL}$ of macerated fungal mycelia [20 mg dry weight (DW)] on the root system over the planting hole. Control plants received $20 \mathrm{~mL}$ of sterile water. Fungal inocula killed by autoclaving were not used as a control, because mineral nutrients released from the dead fungal material would add some nutrients to the soil. We determined that the mycelia used in our experiment contained about $7 \% \mathrm{~N}$.

For ${ }^{15} \mathrm{~N}$-treated plants, $20 \mathrm{~mL}$ of a solution containing $0.1 \mathrm{~g}$ of $\left({ }^{15} \mathrm{NH}_{4}\right)_{2} \mathrm{SO}_{4}\left(>98 \%{ }^{15} \mathrm{~N}\right.$, Cambridge Isotope Laboratories, Andover, Mass.) was applied to a $5 \mathrm{~cm}$ radius area of the root zone around each plant, covered with $1 \mathrm{~cm}$ of soil, and protected by a $30 \times 30 \mathrm{~cm}$ piece of the same polyethylene film used to cover the plot. The $0{ }^{15} \mathrm{~N}$-labeled $\mathrm{N}$ control plants received only $20 \mathrm{~mL}$ of sterile distilled water. There was no other $\mathrm{N}$ fertilizer applied during the experiment. The treatment was applied on $28 \mathrm{Aug}$. 1998 ( 2 months after planting/inoculation). The leaf ${ }^{15} \mathrm{~N}$ enrichment was expressed as atom percentage excess instead of percentage ${ }^{15} \mathrm{~N}$ nitrogen derived from labeled fertilizer (\%NDFF) since the applied labeled-N was almost $100 \%$ enriched.
Immediately following planting and inoculation, plant height, canopy width, and foliage density were recorded as initial growth variables. Initial canopy growth index was then calculated by multiplying initial canopy volume by foliage density (Yang and Goulart, 1997). Leaf photosynthetic rate, transpiration, and stomatal conductance were measured weekly on two fully expanded young leaves per plant from 0900 to $1100 \mathrm{HR}$ during the growing season using a portable infrared gas analyzer (Analytical Development Co., London) and composite data from the last two measurements in the growing season were used for final analysis. One month after ${ }^{15} \mathrm{~N}$ treatment (28 Sept. 1998), plant height, canopy width, foliage density, and leaf color were determined as described in previous studies (Yang and Goulart, 1997; Yang et al., 1996). Final canopy growth index was calculated again. Plants were then excavated and root systems cleaned by gently immersing them in buckets of water and removing manually organic particles associated with the root system. Root system widths, depth, and density (rated on a 1-5 scale, $1=$ sparse, $5=$ dense) were recorded and a root growth index was derived by multiplying root system volume by root system density (Yang and Goulart, 1997). To assess root mycorrhizal infection levels, small amounts of new roots of similar age taken uniformly around the root system of each plant were stained using trypan blue; mycorrhizal infection levels were then determined using a gridline intersect technique (Giovannetti and Mosse, 1980) modified to determine percentage of root epidermal cells infected. Plants were separated into leaves, shoots, and roots, fresh weights recorded, and tissue dried in an oven at $60{ }^{\circ} \mathrm{C}$ for $72 \mathrm{~h}$ for dry weight (DW) determination. Tissues were then ground to pass an 80 mesh (0.318 mm) screen using a sample mill (Cyclotec 1093; Itecator, Stockholm, Sweden). Tissue N concentration and percentage of ${ }^{15} \mathrm{~N}$ enrichment were analyzed by the U.S. Department of Agriculture, Agricultural Research Service, Stable Isotope Laboratory at the University of Nebraska, Lincoln.

All data were analyzed using general linear model (GLM) procedures of SAS (SAS Institute, Inc., 1992). Mycorrhizal infection data were arcsin transformed before analysis of variance (ANOVA), but the original nontransformed means are presented. The final growth variables were analyzed by covariate analysis using the initial canopy growth index as a covariate to account for variation caused by initial plant sizes at planting. Mean separations were conducted by Duncan's multiple range test. For treatment interactions, least square means were compared by using Bonferroni adjustment (Ravindra and Naik, 1999). 


\section{Results}

Plant Growth. Mycorrhizal inoculation significantly affected total plant DW, shoot DW, canopy growth index, and mycorrhizal infection level (Table 1). The first order interactions between soil amendment and $\mathrm{N}$ treatment were significant for all parameters except root to shoot ratio and leaf color. There were also mycorrhizal inoculation $\times$ soil amendment and soil amendment $\times \mathrm{N}$ interactions for mycorrhizal infection levels; however, there were no other first order interactions between mycorrhizal status and soil amendment or mycorrhizal status and $\mathrm{N}$ treatment. No second order interactions were observed for any parameter.

Mycorrhizal plants had more total DW, shoot, and root DW than nonmycorrhizal plants (Table 2). The canopy growth index was also larger in mycorrhizal than nonmycorrhizal plants, however, root to shoot ratio, and root growth index were not different between mycorrhizal and nonmycorrhizal plants. Plants treated with both forest litter and ${ }^{15} \mathrm{~N}$ had the highest total DW, shoot and root DW as well as the largest root and canopy growth index. Plants treated with the rotted sawdust amendment had the lowest total DW and shoot DW and smaller canopy growth index, regardless of $\mathrm{N}$ treatment. For plants growing in soil without any amendment, total plant DW, shoot and root DWs, and canopy growth index were higher than those growing in the rotted sawdust amendment, except for root DW of plants amended with rotted sawdust and ${ }^{15} \mathrm{~N}$.

No treatment interactions were observed for leaf photosynthetic rate (A), transpiration (TR), and water use efficiency (WUE) (Table 3). Neither mycorrhizal inoculation nor $\mathrm{N}$ affected A, TR, or WUE $(P>0.05)$. However, plants treated with ${ }^{15} \mathrm{~N}$ had darker leaf color than those without ${ }^{15} \mathrm{~N}$. Plants treated with the forest litter amendment had the highest A, WUE, and leaf color rating among soil amendment treatments. Plants in soil with no amendment had higher WUE and darker leaf color than those with the rotted sawdust amendment.

Plants with mycorrhizal inoculation had higher mycorrhizal infection levels, while the infection level in plants without inoculation was minimal (Table 4). Among inoculated plants, mycorrhizal infection level was lower in plants amended with rotted sawdust compared to forest litter or no amendment. The interaction between $\mathrm{N}$ and soil amendment for mycorrhizal infection level revealed that higher infection was obtained with the addition

Table 2. Main effect of mycorrhizal inoculation (MI) and interaction between labeled N treatment and soil amendment on growth of 'Elliott' highbush blueberry.

\begin{tabular}{|c|c|c|c|c|c|c|}
\hline $\begin{array}{l}\text { Effect and } \\
\text { interaction }\end{array}$ & $\begin{array}{l}\text { Total } \\
\text { dry wt } \\
(\mathrm{g})\end{array}$ & $\begin{array}{l}\text { Shoot } \\
\text { dry wt } \\
(\mathrm{g})\end{array}$ & $\begin{array}{l}\text { Root } \\
\text { dry wt } \\
(\mathrm{g})\end{array}$ & $\begin{array}{c}\text { Root to } \\
\text { shoot } \\
\text { ratio }\end{array}$ & $\begin{array}{c}\text { Root } \\
\text { growth } \\
\text { index } \\
\left(\mathrm{dm}^{3}\right)\end{array}$ & $\begin{array}{c}\text { Canopy } \\
\text { growth }^{\mathrm{z}} \\
\text { index } \\
\left(\mathrm{dm}^{3}\right)\end{array}$ \\
\hline M & 7.4 & 4.8 & 2.6 & 0.59 & 1.8 & 39.6 \\
\hline NM & 6.3 & 4.1 & 2.2 & 0.58 & 1.5 & 29.1 \\
\hline $\mathrm{N}$, forest litter & $12.1 \mathrm{~d}^{\mathrm{w}}$ & $8.2 \mathrm{~d}$ & $3.9 \mathrm{c}$ & NA & $3.6 \mathrm{~d}$ & $72.3 \mathrm{e}$ \\
\hline $\mathrm{N}$, rotted sawdust & $3.3 \mathrm{a}$ & $2.0 \mathrm{a}$ & $1.3 \mathrm{a}$ & NA & $0.3 \mathrm{a}$ & $10.8 \mathrm{a}$ \\
\hline $\mathrm{N}$, no amendment & $6.8 \mathrm{bc}$ & $4.6 \mathrm{bc}$ & $2.3 \mathrm{ab}$ & NA & $1.6 \mathrm{abc}$ & $30.6 \mathrm{bc}$ \\
\hline No N, forest litter & $8.9 \mathrm{c}$ & $5.9 \mathrm{c}$ & $3.0 \mathrm{bc}$ & NA & $2.0 \mathrm{c}$ & $50.6 \mathrm{~d}$ \\
\hline No N, rotted sawdust & $3.6 \mathrm{a}$ & $2.1 \mathrm{a}$ & $1.5 \mathrm{a}$ & NA & $0.7 \mathrm{ab}$ & $12.3 \mathrm{a}$ \\
\hline No N, no amendment & $6.4 \mathrm{~b}$ & $3.9 \mathrm{~b}$ & $2.5 \mathrm{~b}$ & NA & $1.8 \mathrm{bc}$ & $29.4 \mathrm{~b}$ \\
\hline
\end{tabular}

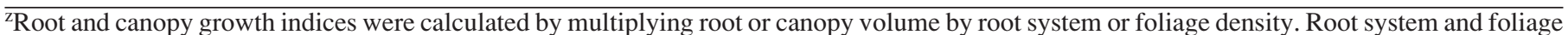
density were rated subjectively based on a $1-5$ scale $(1=$ sparse, $5=$ dense) (Yang and Goulart, 1997).

${ }^{y}$ Effect was adjusted using covariate except for dependent variable of leaf color. $\mathrm{M}=$ mycorrhizal, $\mathrm{NM}=$ nonmycorrhizal, $\mathrm{N}=$ labeled $\mathrm{N}$ treatment, $\mathrm{SA}=$ soil amendment, and $\mathrm{NA}=$ not applicable, because $\mathrm{N}$ and soil amendment did not interact.

${ }^{x} P(F)$ values indicate significance level.

${ }^{\text {w} F o r ~} \mathrm{~N} \times \mathrm{SA}$ interactions, least square means were Bonferroni adjusted (Ravindra and Naik, 1999). Mean separation for N $\times$ SA interaction within columns by Duncan's multiple range test at $P=0.05$.

Table 3. Effect of soil amendment on C assimilation of 'Elliott' highbush blueberry and associated parameters. ${ }^{\mathrm{Z}}$

\begin{tabular}{|c|c|c|c|c|}
\hline $\begin{array}{l}\text { Soil } \\
\text { treatment }\end{array}$ & $\begin{array}{c}\mathrm{CO}_{2} \\
\text { assimilation } \\
\text { rate } \\
\left(\mu \mathrm{mol} \cdot \mathrm{m}^{-2} \cdot \mathrm{s}^{-1}\right)\end{array}$ & $\begin{array}{l}\text { Transpiration } \\
\text { rate } \\
\left(\mathrm{mmol} \cdot \mathrm{m}^{-2} \cdot \mathrm{s}^{-1}\right)\end{array}$ & $\begin{array}{c}\text { Water } \\
\text { use } \\
\text { efficiency } \\
\left(\mu \mathrm{mol} \cdot \mathrm{mmol}^{-1}\right)^{\mathrm{y}}\end{array}$ & $\begin{array}{c}\text { Leaf } \\
\text { color }^{x}\end{array}$ \\
\hline Forest litter & $7.8 \mathrm{~b}^{\mathrm{w}}$ & $1.2 \mathrm{a}$ & $6.6 \mathrm{c}$ & $4.3 \mathrm{c}$ \\
\hline Rotted sawdust & $3.6 \mathrm{a}$ & $1.3 \mathrm{a}$ & $2.8 \mathrm{a}$ & $2.2 \mathrm{a}$ \\
\hline No amendment & $4.8 \mathrm{a}$ & $1.1 \mathrm{a}$ & $4.6 \mathrm{~b}$ & $3.3 \mathrm{~b}$ \\
\hline
\end{tabular}

${ }^{\mathrm{z}}$ Composite data of two measurements during the final month of growth.

${ }^{\mathrm{y}}$ Water use efficiency was calculated by dividing $\mathrm{CO}_{2}$ assimilation rate by transpiration rate.

${ }^{x}$ Leaf color was rated based on a $1-5$ scale with $1=$ reddish yellow, $5=$ dark green.

${ }^{\text {w }}$ Mean separation within columns by Duncan's multiple range test at $P=0.05$.

${ }^{\mathrm{v}} P(\mathrm{~F})$ values indicate significance level. 
Table 4. Effect of mycorrhizal inoculation (MI), labeled N treatment, and soil amendment on mycorrhizal infection levels in 'Elliott' highbush blueberry. ${ }^{\mathrm{z}}$

\begin{tabular}{lc}
\hline \hline $\begin{array}{l}\text { Treatment } \\
\text { interaction }\end{array}$ & $\begin{array}{c}\text { Mycorrhizal } \\
\text { infection }(\%)\end{array}$ \\
\hline MI $\times$ SA $^{\mathrm{y}}$ & $25.6 \mathrm{c}^{\mathrm{x}}$ \\
M, forest litter & $13.5 \mathrm{~b}$ \\
M, rotted sawdust & $25.3 \mathrm{c}$ \\
M, no amendment & $0.6 \mathrm{a}$ \\
NM, forest litter & $0.4 \mathrm{a}$ \\
NM, rotted sawdust & $0.1 \mathrm{a}$ \\
NM, no amendment & \\
N $\times$ SA & $12.0 \mathrm{bc}^{\mathrm{y}}$ \\
N, forest litter & $4.8 \mathrm{a}$ \\
N, rotted sawdust & $7.5 \mathrm{a}$ \\
N, no amendment & $6.3 \mathrm{a}$ \\
No N, forest litter & $4.7 \mathrm{a}$ \\
No N, rotted sawdust & $7.7 \mathrm{ab}$ \\
No N, no amendment
\end{tabular}

${ }^{\mathrm{z}}$ Data presented are nontransformed means.

${ }^{\mathrm{y}} \mathrm{M}=$ mycorrhizal, $\mathrm{NM}=$ nonmycorrhizal, $\mathrm{N}=$ labeled $\mathrm{N}$ treatment, and $\mathrm{SA}=$ soil amendment.

${ }^{x}$ Least square means were Bonferroni adjusted (Ravindra and Naik, 1999). Mean separation within column by Duncan's multiple range test at $P=0.05$.

of forest litter and ${ }^{15} \mathrm{~N}$. Plants with all other treatment combinations showed lower infection levels except for those with no amendment and no ${ }^{15} \mathrm{~N}$.

LEAF NITROGEN. Mycorrhizal inoculation significantly increased total leaf $\mathrm{N}$ and nonlabeled leaf $\mathrm{N}$ content per plant (Table 5). Effects of soil amendment and $\mathrm{N}$ were significant for all the $\mathrm{N}$ related parameters except for the effect of $\mathrm{N}$ treatment on total nonlabeled leaf $\mathrm{N}$ content. There were no significant interactions between mycorrhizal inoculation and soil amendment. However, the interactions between mycorrhizal inoculation and $\mathrm{N}$, and soil amendment and $\mathrm{N}$ were significant for leaf ${ }^{15} \mathrm{~N}$ enrichment. The interactive effect of soil amendment and $\mathrm{N}$ was also significant for leaf ${ }^{15} \mathrm{~N}$ content. The second order interaction was not significant for any of the N-related parameters.

There was no difference in leaf $\mathrm{N}$ concentration between mycorrhizal treatments (Table 6). However, labeled-N-treated plants had higher leaf $\mathrm{N}$ concentrations than control plants. Plants amended with rotted sawdust had lower leaf $\mathrm{N}$ concentrations compared to plants with forest litter or no amendment. Leaf $\mathrm{N}$ concentrations did not differ between plants with forest litter amendment and plants with no amendment. There were both inoculation $\times \mathrm{N}$, and soil amendment $\times \mathrm{N}$ interactions for leaf ${ }^{15} \mathrm{~N}$ enrichment. No differences in leaf ${ }^{15} \mathrm{~N}$ enrichment were observed between mycorrhizal and nonmycorrhizal plants that received no labeled $\mathrm{N}$. However, with ${ }^{15} \mathrm{~N}$-labeled $\mathrm{N}$ application, mycorrhizal plants showed less leaf ${ }^{15} \mathrm{~N}$ enrichment than nonmycorrhizal plants. Furthermore, ${ }^{15} \mathrm{~N}$-treated plants amended with forest litter also had less leaf ${ }^{15} \mathrm{~N}$ enrichment than plants amended with rotted sawdust. There was no difference in leaf ${ }^{15} \mathrm{~N}$ enrichment between plants with rotted sawdust or no amendment.

Mycorrhizal plants had higher total leaf $\mathrm{N}$ and nonlabeled leaf N content than nonmycorrhizal plants (Table 7). Plants receiving ${ }^{15} \mathrm{~N}$ had more total leaf $\mathrm{N}$ content but not nonlabeled $\mathrm{N}$ content. Application of forest litter amendment resulted in the highest total leaf $\mathrm{N}$ content and nonlabeled $\mathrm{N}$ content followed by no amendment and rotted sawdust amendment. There was no difference in leaf ${ }^{15} \mathrm{~N}$ content between mycorrhizal and nonmycorrhizal plants.

\section{Discussion}

Plant Growth. Effects of ericoid mycorrhizal inoculation on growth of blueberry have been inconsistent among various studies. While inoculation increased blueberry growth in the field (Powell and Bates, 1981), mycorrhizal inoculation with pure cultured Hymenosyphus ericae showed little effect on plant growth in vitro and in greenhouse studies (Reich et al., 1982). Inconsistent effects of mycorrhizal inoculation may have occurred from lack of appropriate nonmycorrhizal controls or the source of inoculum used in the aforementioned studies. In the current study, mycorrhizal inoculation increased plant DW and most other growth parameters (Table 2). However, leaf photosynthetic rate, transpiration, and water use efficiency were not significantly affected by mycorrhizal inoculation (Table 3). This is somewhat surprising, since some studies have reported increased leaf photosynthetic rates as a result of ectomycorrhizal infection due possibly to $\mathrm{C}$ drain to support the mycorrhizal fungi (Dosskey et al., 1990). Ericoid mycorrhizae, however, are capable of transferring $\mathrm{C}$ and $\mathrm{N}$ simultaneously to the host plants, when using organic sources of $\mathrm{N}$ such as amino acids (Stribley and Read, 1974b), therefore the C drain may be offset in part by this small gain. The increased DW in mycorrhizal plants may have been a combination of increased mineral nutrient acquisi-

Table 5. ANOVA for leaf ${ }^{15} \mathrm{~N}$, total leaf $\mathrm{N}$ content, and $\mathrm{N}$ concentration of 'Elliott' highbush blueberry.

\begin{tabular}{|c|c|c|c|c|c|c|}
\hline Effect $^{\mathrm{z}, \mathrm{y}}$ & $\mathrm{df}$ & $\begin{array}{c}\text { Leaf } \\
\mathrm{N} \\
\text { concn } \\
(\%)\end{array}$ & $\begin{array}{c}\text { Total } \\
\text { leaf } \mathrm{N} \\
\text { content } \\
\text { (g/plant) }\end{array}$ & $\begin{array}{c}\text { Total } \\
\text { leaf }{ }^{15} \mathrm{~N} \\
\text { content } \\
\text { (g/plant) }\end{array}$ & $\begin{array}{c}\text { Total } \\
\text { nonlabeled } \\
\text { leaf } \mathrm{N} \\
\text { content } \\
\text { (g/plant) }\end{array}$ & $\begin{array}{c}\text { Leaf }{ }^{15} \mathrm{~N} \\
\text { enrichment } \\
\text { (atom \% excess) }\end{array}$ \\
\hline$\overline{\mathrm{MI}}$ & 1 & NS & $*$ & NS & $*$ & $*$ \\
\hline $\mathrm{SA}$ & 2 & $* * *$ & $* * *$ & $* * *$ & $* * *$ & $* * *$ \\
\hline $\mathrm{MI} \times \mathrm{SA}$ & 2 & NS & NS & NS & NS & NS \\
\hline $\mathrm{N}$ & 1 & $* * *$ & $* *$ & $* * *$ & NS & $* * *$ \\
\hline $\mathrm{MI} \times \mathrm{N}$ & 1 & NS & NS & NS & NS & $*$ \\
\hline $\mathrm{SA} \times \mathrm{N}$ & 2 & NS & NS & $* * *$ & NS & $*$ \\
\hline $\mathrm{MI} \times \mathrm{SA} \times \mathrm{N}$ & 2 & NS & NS & NS & NS & NS \\
\hline
\end{tabular}

${ }^{\mathrm{z}} \mathrm{MI}=$ mycorrhizal inoculation, $\mathrm{SA}=$ soil amendment, and $\mathrm{N}=$ nitrogen treatment.

yEffect was adjusted using covariate (initial total growth) except for dependent variables of leaf color and infection.

Ns,*,***** Nonsignificant or significant at $P=0.05,0.01$, or 0.001 , respectively. 
tion and less C drain from the host (Read, 1991; Read et al., 1989), and/or a lower $\mathrm{C}$ cost per unit of nutrient (e.g., N) return in ericoid mycorrhizal symbiosis.

Rotted sawdust mulch and/or soil amendments have been shown to increase growth and yield of highbush blueberry (Goulart et al., 1995b). However, an early study found that use of rotted sawdust amendment following soil fumigation suppressed highbush blueberry growth in the first growing season, suggesting that soil organic amendment might have affected mineralization of soil N (Yang et al., 1998). In the current study, such a possibility was explored further by using a forest litter amendment and rotted sawdust. Clearly, forest litter increased plant DW and size, leaf photosynthetic rate, and WUE. In contrast, plant growth and leaf photosynthetic rate were significantly reduced by rotted sawdust, supporting findings of the earlier study of Yang et al. (1998). The quality of organic amendments can greatly affect soil $\mathrm{N}$ mineralization processes. It is generally believed that the $\mathrm{C}$ to $\mathrm{N}$ ratio of the organic materials in soils is one of the most deciding factors

Table 6. Effect of mycorrhizal inoculation (MI), labeled $\mathrm{N}$ treatment, and soil amendment on leaf $\mathrm{N}$ concentration and ${ }^{15} \mathrm{~N}$ enrichment in 'Elliott' highbush blueberry.

\begin{tabular}{|c|c|c|c|}
\hline Effect $^{2}$ & $\begin{array}{l}\text { Leaf } \mathrm{N} \\
\text { concn } \\
(\%)\end{array}$ & Effect & $\begin{array}{c}\text { Leaf }{ }^{15} \mathrm{~N} \\
\text { enrichment } \\
\text { (atom \% excess) }\end{array}$ \\
\hline Main MI effect & & $\mathrm{MI} \times \mathrm{N}$ interaction & \\
\hline NM & 1.7 & $\mathrm{NM}, \mathrm{N}$ & $20.5 \mathrm{c}$ \\
\hline \multirow[t]{2}{*}{$P(\mathrm{~F})^{\mathrm{x}}$} & 0.13 & $\mathrm{M}, \mathrm{No} \mathrm{N}$ & $0.5 \mathrm{a}$ \\
\hline & & NM, No N & $0.5 \mathrm{a}$ \\
\hline No N & 1.6 & & \\
\hline \multirow[t]{2}{*}{$P(\mathrm{~F})$} & $<0.001$ & $\mathrm{SA} \times \mathrm{N}$ interaction & \\
\hline & & $\mathrm{N}$, forest litter & $14.1 \mathrm{~b}$ \\
\hline Main SA effect & & $\mathrm{N}$, rotted sawdust & $21.4 \mathrm{c}$ \\
\hline Forest litter & $1.9 \mathrm{~b}$ & $\mathrm{~N}$, no amendment & $18.3 \mathrm{bc}$ \\
\hline
\end{tabular}

${ }^{\mathrm{z}} \mathrm{M}=$ mycorrhizal, $\mathrm{NM}=$ nonmycorrhizal, $\mathrm{N}=$ nitrogen treatment, and $\mathrm{SA}=$ soil amendment.

'Least square means were Bonferroni adjusted (Ravindra and Naik, 1999). For each interaction, mean separation within columns by Duncan's multiple range test at $P=0.05$.

${ }^{x} P(\mathrm{~F})$ values indicate significance level.

Table 7. Effect of mycorrhizal inoculation (MI), labeled N treatment, and soil amendment on leaf N content in 'Elliott' highbush blueberry.

\begin{tabular}{|c|c|c|c|c|}
\hline Effect $^{z, y}$ & $\begin{array}{c}\text { Total } \\
\text { leaf } \\
\mathrm{N} \\
\text { (mg/plant) }\end{array}$ & $\begin{array}{c}\text { Total } \\
\text { unlabeled } \\
\text { leaf } \\
\mathrm{N}^{\mathrm{y}} \\
\text { (mg/plant) }\end{array}$ & $\begin{array}{l}\text { Effect and } \\
\text { interaction }^{z, y}\end{array}$ & $\begin{array}{c}\text { Total } \\
\text { leaf } \\
{ }^{15} \mathrm{~N} \\
\text { (mg/plant) }\end{array}$ \\
\hline Main MI effect & & & Main MI effect & \\
\hline M & 52 & 48 & M & 4.3 \\
\hline NM & 37 & 34 & NM & 3.9 \\
\hline Main N effect & & & $\mathrm{N} \times \mathrm{SA}$ interaction & \\
\hline $\mathrm{N}$ & 55 & 46 & & \\
\hline No N & 36 & 35 & $\mathrm{~N}$, Forest litter & $11.4 \mathrm{~d}^{\mathrm{w}}$ \\
\hline \multirow[t]{2}{*}{$P(\mathrm{~F})$} & $<0.001$ & 0.059 & N, Rotted sawdust & $4.6 \mathrm{~b}$ \\
\hline & & & $\mathrm{N}$, No amendment & $8.1 \mathrm{c}$ \\
\hline Main SA effect & & & No N, Forest litter & $0.3 \mathrm{a}$ \\
\hline
\end{tabular}

${ }^{\mathrm{z}}$ Total nonlabeled leaf $\mathrm{N}=$ total leaf $\mathrm{N}-$ total leaf ${ }^{15} \mathrm{~N}$.

${ }^{\mathrm{y}} \mathrm{M}=$ mycorrhizal, $\mathrm{NM}=$ nonmycorrhizal, $\mathrm{N}=$ nitrogen treatment, and $\mathrm{SA}=$ soil amendment.

${ }^{x} P(F)$ values indicate significance level.

wLeast square means were Bonferroni adjusted (Ravindra and Naik, 1999). Mean separation within column by Duncan's multiple range test at $P$ $=0.05$. 
affecting soil $\mathrm{N}$ mineralization (Tate, 1995). Organic material with a $\mathrm{C}$ to $\mathrm{N}$ ratio $<30$ : 1 would result in net $\mathrm{N}$ mineralization (Tisdale et al., 1993). The $\mathrm{C}$ to $\mathrm{N}$ ratios of the forest litter and rotted sawdust were 19:1 and 59:1 respectively. It is likely that the decomposing forest litter released more $\mathrm{N}$ available for plant uptake while decomposition of rotted sawdust contributed little available $\mathrm{N}$, and immobilized mineralized soil $\mathrm{N}$, thus resulting in the growth differences between these two organic amendments. To compensate for the $\mathrm{N}$ used by microbes to decompose rotted sawdust, additional $\mathrm{N}$ fertilizer is required to sustain plant growth. This is why more fertilizer $\mathrm{N}$ is recommended commercially if rotted sawdust is used as organic mulch (Goulart et al., 1995 b). However, the question of how much more $\mathrm{N}$ should be applied according to the $\mathrm{C}$ to $\mathrm{N}$ ratio of the organic material still remains unanswered.

One needs to realize that the current study employed a manipulated system to address issues related to commercial blueberry production. The soil fumigants used at a high lethal rate in the current investigation had effectively eradicated indigenous mycorrhizal fungi, including those present in the organic amendments (Yang et al., 1998). Thus, it was unlikely for the forest litter to provide potential mycorrhizal inocula during the experiment. The high rate of fumigants probably also eliminated soil $\mathrm{S}$ oxidizing bacteria, but these bacteria could be highly inducible at the presence of a large amount of elemental S in the soil (Tate, 1995). As observed in the current study, following soil fumigation, the $\mathrm{pH}$ in soils incorporated with elemental $\mathrm{S}$ powder was decreased from 6.5 to 5.2 on average at the end of a 3-month period, which was consistent with a previous study (Yang et al., 1998). Because the soil saprophytes and nitrifiers may have also been destroyed after soil fumigation, it was possible that the $\mathrm{N}$ mineralization processes were carried out mainly by ericoid mycorrhizal fungi, which are capable of functioning as soil saprophytes to break down soil organic matter, proteins, and peptides via production of a variety of extracellular enzymes (Bajwa and Read, 1985; Bajwa et al., 1985; Read, 1991). Furthermore, mycorrhizal roots are able to take up organic forms of $\mathrm{N}$ such as amino acids and small peptides, and transport them to the host plants (Bajwa and Read, 1985; Bajwa et al., 1985). However, the effectiveness of mycorrhizal fungi on $\mathrm{N}$ mineralization and plant $\mathrm{N}$ uptake may depend on the mycorrhizal fungal species and the intensity of mycorrhizal infection.

MYCORRHIZAL InfECTION LEVEL. Overall, mycorrhizal infection levels observed in the current study were comparable to our previous field study (Yang et al., 1998) but higher than our greenhouse studies (Yang and Goulart, 1997; Yang et al., 1996). These were probably due to use of the same or different fungal species among these studies and/or the other experimental conditions. Mycorrhizal infection levels can also be affected by soil $\mathrm{N}$ availability. Studies in controlled environments and the field have found that low $\mathrm{N}$ levels $(20 \mathrm{~mm} \mathrm{~N})$ increase mycorrhizal infection (Goulart et al., 1995b, 1996a; Stribley and Read, 1976). It is believed that the ability of ericaceous plants to forage for $\mathrm{N}$ is increased by mycorrhizal infection, especially under $20 \mathrm{~mm} \mathrm{~N}$ (Stribley and Read, 1976). However, if soil available $\mathrm{N}$ is so low that it reduces plant growth, establishment of the mycorrhizal association may be affected. In the current study, mycorrhizal infection level was reduced in plants treated with rotted sawdust compared to those treated with forest litter or no amendment. This reduction in mycorrhizal infection level may be the result of $\mathrm{N}$ stress to plants caused by sawdust decomposition. In our previous field studies, lower mycorrhizal infection levels were found when plants were mulched using rotted sawdust (Goulart et al., 1995b). A follow-up study suggested that sawdust amendment decreased total root length, which resulted in a decrease in mycorrhizal infection levels (Goulart et al., 1998).

Nitrogen deficiency in plants may contribute to low root carbohydrate content which lowers infection levels in vesiculararbuscular mycorrhizal associations (Hepper, 1983; Same et al., 1983). In the current study, the limited N supply to the host plants could have resulted in a reduced $\mathrm{C}$ supply to support mycorrhizal association, thus leading to a reduced mycorrhizal infection level. Similarly, addition of $\mathrm{N}$ to the soil with the forest litter amendment could alleviate competition for soil $\mathrm{N}$ during organic matter decomposition and increase root $\mathrm{C}$ supply, thus resulting in a higher mycorrhizal infection level.

LEAF ${ }^{15}$ N ENRICHMENT AND CONTENT. Plants treated with mycorrhizal inoculation, labeled $\mathrm{N}$, forest litter, and no amendment showed sufficient leaf $\mathrm{N}$ concentrations compared to leaf $\mathrm{N}$ standard $(1.7 \%)$ in highbush blueberry. Nonmycorrhizal plants and the plants treated with no labeled $\mathrm{N}$ and rotted sawdust were deficient in their leaf $\mathrm{N}$ concentrations. Because total plant $\mathrm{N}$ content was not determined, whole plant $\mathrm{N}$ uptake can not be discussed. Also, since highly enriched labeled $\mathrm{N}$ fertilizer was used during the experiment, much of the discussion deals with leaf $\mathrm{N}$ concentration and leaf ${ }^{15} \mathrm{~N}$ content.

In the current study, leaf $\mathrm{N}$ concentration was the same for mycorrhizal and nonmycorrhizal plants. When labeled inorganic $\mathrm{N}$ was applied, mycorrhizal plants accumulated less labeled $\mathrm{N}$ in their leaves. This reduction in leaf ${ }^{15} \mathrm{~N}$ enrichment in mycorrhizal plants yields several possible explanations. First, mycorrhizal plants may have acquired more available soil $\mathrm{N}$ (labeled or nonlabeled $\mathrm{N}$ ) than their nonmycorrhizal counterparts, thus resulting in a dilution in leaf ${ }^{15} \mathrm{~N}$ enrichment. Secondly, the pool of soil inorganic $\mathrm{N}$ may have been increased by mycorrhizal inoculation (e.g., by increasing organic matter decomposition and $\mathrm{N}$ mineralization), resulting in lowered enrichment in soil inorganic N pool. Finally, as suggested by Stribley and Read (1974a) in their ${ }^{15} \mathrm{~N}$ labeling experiment, the decrease in leaf ${ }^{15} \mathrm{~N}$ enrichment due to mycorrhizal infection suggests that mycorrhizal plants were able to access nonlabeled soil organic $\mathrm{N}$ before ammonification. Similarly, in our study, less leaf ${ }^{15} \mathrm{~N}$ enrichment in mycorrhizal plants may indicate that more nonlabeled soil $\mathrm{N}$ was acquired in mycorrhizal than in nonmycorrhizal plants, which was indeed supported by the higher nonlabeled leaf $\mathrm{N}$ content in mycorrhizal plants. Since applied inorganic N was labeled, nonlabeled $\mathrm{N}$ must derive from soil organic $\mathrm{N}$ sources or from inorganic $\mathrm{N}$ mineralized from these organic $\mathrm{N}$ sources. In a series of laboratory studies, it was concluded that only mycorrhizal plants were able to use organic N sources (Bajwa and Read, 1985, 1986; Read, 1991; Stribley and Read, 1980). In the current field study, we demonstrated the possibility that mycorrhizal blueberry plants could acquire more nonlabeled soil $\mathrm{N}$ either from mineralized $\mathrm{N}$ from organic sources or directly from soil organic $\mathrm{N}$ sources.

Differences in leaf $\mathrm{N}$ concentration and leaf ${ }^{15} \mathrm{~N}$ enrichment between plants exposed to the two soil amendments support further the $\mathrm{C}$ to $\mathrm{N}$ ratio theory discussed earlier. Because there was less leaf ${ }^{15} \mathrm{~N}$ enrichment in plants amended with forest litter, more organic $\mathrm{N}$ could be available for plants treated with the forest litter amendment. Similarly, more leaf ${ }^{15} \mathrm{~N}$ enrichment in plants amended with rotted sawdust meant less available organic $\mathrm{N}$ was present in the soil, possibly due to $\mathrm{N}$ immobilization.

The organic amendments used in the present study clearly 
affected plant growth and ability to forage for soil N. However, the role of mycorrhizal fungi in the decomposition of organic amendments and the release of organic $\mathrm{N}$ was not clear (i.e., no interaction between mycorrhizal inoculation and soil amendment). This may have been due to the complicating fact that under field conditions, other soil microbes may have affected the processes of organic matter decomposition and $\mathrm{N}$ mineralization, even though their effects on these processes would be minimized following soil fumigation. It may also be that decomposition of organic materials in the soil takes a longer time than the oneseason span of this experiment. In mineral soil production systems, it is clear that we have to consider the quality (i.e., chemical properties) of the organic mulch and/or amendment. As demonstrated in the current study, if more $\mathrm{N}$ is not added, an organic amendment with a high $\mathrm{C}$ to $\mathrm{N}$ ratio ( $>30: 1)$ reduces plant growth, probably by immobilizing soil $\mathrm{N}$. Fertilizer $\mathrm{N}$ applied in such conditions may be used by soil microbes (including mycorrhizal fungi) to decompose $\mathrm{C}$ rich organic matter rather than by plants. Therefore, organic mulch or amendments with lower $\mathrm{C} / \mathrm{N}$ ratios $(<30: 1)$ should be considered in these production systems. Because mycorrhizal infection clearly gives the host plant an advantage in acquiring soil $\mathrm{N}$, isolation and identification of competitive ericoid mycorrhizal strains with high $\mathrm{N}$ forage ability warrants further study.

\section{Literature Cited}

Abuzinadah, R.A. and D.J. Read. 1986. The role of proteins in the nitrogen nutrition of ectomycorrhizal fungi. New Phytol. 103:481493.

Bajwa, R., S. Abuarghub, and D.J. Read. 1985. The biology of mycorrhiza in the ericaceae $X$. The utilization of proteins and the production of proteolytic enzymes by the mycorrhizal endophyte and by mycorrhizal plants. New Phytol. 101:469-486.

Bajwa, R. and D.J. Read. 1985. The biology of mycorrhiza in the ericaceae. IX. Peptides as nitrogen sources for the ericoid endophyte and for mycorrhizal and non-mycorrhizal plants. New Phytol. 101:459_ 467.

Bajwa, R. and D.J. Read. 1986. Utilization of mineral and amino N sources by the ericoid mycorrhizal endophyte Hymenoscyphus ericae and by mycorrhizal and non-mycorrhizal seedlings of Vaccinium. Trans. Brit. Mycol. Soc. 87:269-277.

Barron, G.L. 1962. New species and new records of Oidiodendron. Can. J. Bot. 40:589-607.

Boyer, E.P., J.R. Ballington, and C.M. Mainland. 1982. Endomycorrhizae of Vaccinium corymbosum L. in North Carolina. J. Amer. Soc. Hort. Sci. 107:751-754.

Dosskey, M.G., R.G. Linderman, and L. Boersma. 1990. Carbon-sink stimulation of photosynthesis in douglas fir seedlings by some ectomycorrhizas. New Phytol. 115:269-274.

Giovannetti, M. and B. Mosse. 1980. An evaluation of techniques for measuring vesicular arbuscular mycorrhizal infection in roots. New Phytol. 84:489-500.

Gough, R.E., V.G. Shutake, and D.B. Wallace. 1977. Highbush blueberry culture. R.I. Coop. Ext. Ser. Bul. 143.

Goulart, B.L., M. Brittingham, J. Harper, P. Heinemann, and W. Hock. 1996b. Small fruit production and pest management guide, 1996-98. Pa. State Univ. Ext. Publ.

Goulart, B.L., K. Demchak, M.L. Schroeder, and J.R. Clark. 1993. Mycorrhizae in highbush blueberries: Survey results and field response to nitrogen. HortScience 28:140.

Goulart, B.L., K. Demchak, and W.Q. Yang. 1995b. Organic matter and nitrogen level effects on mycorrhizal infection in 'Bluecrop' highbush blueberry plants. J. Small Fruit Viticult. 3:151-164.

Goulart, B.L., K. Demchak, and W.Q. Yang. 1996a. Effect of cultural practices on field grown 'Bluecrop' highbush blueberries, with empha- sis on mycorrhizal infection levels. Acta Hort. 46:271-278.

Goulart, B.L., K. Demchak, and W.Q. Yang. 1998. Highbush blueberry root systems: Cultural management effects on root system development and mycorrhizal infection intensity. 8th N. Amer. Blueberry Res. Ext. Workers Conf., N.C. State Univ., Raleigh, 12 May 1998.

Goulart, B.L., W.Q. Yang, and K. Demchak. 1995a. Development of an inoculation system for studying mycorrhizal effects in highbush blueberry. J. Small Fruit Viticult. 3:193-201.

Hepper, C.M. 1983. The effect of nitrate and phosphate on the vesiculararbuscular mycorrhizal infection of lettuce. New Phytol. 93:389-399.

Jacobs, L.A., F.S. Davies, and J.M. Kimbrough. 1982. Mycorrhizal distribution in Florida rabitteye blueberries. HortScience 17:951-953. Michelsen, A., I.K. Schmidt, and D. Sleep. 1996. Leaf ${ }^{15} \mathrm{~N}$ abundance of subarctic plants provides field evidence that ericoid, ectomycorrhizal and non- and arbuscular mycorrhizal species access different sources of soil nitrogen. Oecologia 105:53-63.

Mitchell, D.T. and D.J. Read. 1981. Utilization of inorganic and organic phosphates by the mycorrhizal endophytes of Vaccinium macrocarpon and Rhododendron ponticum. Trans. Brit. Mycol. Soc. 76:225-260.

Powell, C.L. and P.M. Bates. 1981. Ericoid mycorrhizas stimulate fruit yield of blueberry. HortScience 16:655-656.

Ravindra, K. and D.N. Naik. 1999. Applied multivariate statistics with SAS software, version 2 ed. SAS Inst., Inc., Cary, N.C.

Read, D.J. 1991. Mycorrhizas in ecosystems. Experientia 47:376-390.

Read, D.J., J.R. Leake, and A.R. Langdale. 1989. The nitrogen nutrition of mycorrhizal fungi and their host plants, p. 181-204. In: L. Boddy, R. Marchant, and D.J. Read (eds.). Nitrogen, phosphorous and sulphur utilization by fungi. Cambridge Univ. Press, New York.

Reich, L.A., R.F. Korcak, and A.H. Thompson. 1982. Effects of two mycorrhizal isolates on highbush blueberry at two soil $\mathrm{pH}$ levels. HortScience 17:642-644.

Same, B.I., A.D. Robson, and L.K. Abbott. 1983. Phosphorus, soluble carbohydrates and endomycorrhizal infection. Soil Biol. Biochem. 15:593-597.

SAS Institute, Inc. 1992. SAS user's guide: Statistics, version 5 ed. SAS Inst., Inc., Cary, N.C.

Stevens, C.M., B.L. Goulart, D. Yolande, J.F. Hancock, K. Demchak, and W.Q. Yang. 1996. The presence, isolation and characterization of ericoid mycorrhizal symbionts in 2 native and 2 commercial Vaccinium populations in central Pennsylvania. Acta Hort. 46:411-420.

Stribley, D.P. and D.J. Read. 1974a. The biology of mycorrhiza in the ericaceae. IV. The effect of mycorrhizal infection on uptake of ${ }^{15} \mathrm{~N}$ from labeled soil by Vaccinium macrocarpon Ait. New Phytol. 73:11491155 .

Stribley, D.P. and D.J. Read. 1974b. The biology of mycorrhiza in Ericaceae. III. Movement of Carbon-14 from host to fungus. New Phytol. 73:731-741.

Stribley, D.P. and D.J. Read. 1976. The biology of mycorrhiza in the ericaceae VI. The effects of mycorrhizal infection and concentration of ammonium nitrogen on growth of cranberry (Vaccinium macrocarpon Ait.) in sand culture. New Phytol. 77:63-72.

Stribley, D.P. and D.J. Read. 1980. The biology of mycorrhiza in the ericaceae. VII. The relationship between mycorrhizal infection and the capacity to utilize simple and complex organic nitrogen sources. New Phytol. 86:365-371.

Tate, R.L. 1995. Soil microbiology. Wiley, New York.

Tisdale, S.L., W.L. Nelson, J.D. Beaton, and J.L. Havlin. 1993. Soil fertility and fertilizers. Macmillan, New York.

Yang, W.Q. and B.L. Goulart. 1997. Aluminum and phosphorus interactions in mycorrhizal and nonmycorrhizal highbush blueberry plantlets. J. Amer. Soc. Hort. Sci. 122:24-30.

Yang, W.Q., B.L. Goulart, and K. Demchak. 1996. The effect of aluminum and media on the growth of mycorrhizal and nonmycorrhizal highbush blueberry plantlets. Plant Soil 183:301-308.

Yang, W.Q., B.L. Goulart, and K. Demchak. 1998. Mycorrhizal infection and plant growth of highbush blueberry in fumigated soil following soil amendment and inoculation with mycorrhizal fungi. HortScience 33:1136-1137. 